Article

\title{
First High-Frequency Underway Observation of DMS Distribution in the Southern Ocean during Austral Autumn
}

\author{
Intae Kim ${ }^{1}\left(\mathbb{D}\right.$, Miming Zhang $^{2}$, Kitae Kim $^{3} \mathbb{D}$ and Keyhong Park ${ }^{3, *}$ \\ 1 Marine Environmental Research Center, Korea Institute of Ocean Science and Technology (KIOST), \\ Busan 49111, Korea; ikim@kiost.ac.kr \\ 2 Key Laboratory of Global Change and Marine-Atmospheric Chemistry, Third Institute of Oceanography, \\ Xiamen 361005, China; zhangmiming@tio.org.cn \\ 3 Korea Polar Research Institute (KOPRI), Incheon 21990, Korea; ktkim@kopri.re.kr \\ * Correspondence: keyhongpark@kopri.re.kr
}

Citation: Kim, I.; Zhang, M.; Kim, K.;

Park, K. First High-Frequency

Underway Observation of DMS Distribution in the Southern Ocean during Austral Autumn. Atmosphere 2021, 12, 122. https://doi.org/ 10.3390/atmos12010122

Received: 20 November 2020 Accepted: 15 January 2021 Published: 16 January 2021

Publisher's Note: MDPI stays neutral with regard to jurisdictional clai$\mathrm{ms}$ in published maps and institutional affiliations.

Copyright: (C) 2021 by the authors. Licensee MDPI, Basel, Switzerland. This article is an open access article distributed under the terms and conditions of the Creative Commons Attribution (CC BY) license (https:// creativecommons.org/licenses/by/ $4.0 /)$.

\begin{abstract}
We investigate the distribution of dimethyl sulfide (DMS) in the Southern Ocean's $\left(50^{\circ} \mathrm{W}\right.$ to $170^{\circ} \mathrm{W}$ ) surface water, including the Antarctic Peninsula and the marginal sea ice zone (MIZ) in the Ross and Amundsen Seas. This is the first high-frequency observation conducted in the austral autumn (in April) in the Southern Ocean. The mean DMS concentration was $2.7 \pm 2.5 \mathrm{nM}(1 \sigma)$ for the entire study area. Noticeably enhanced DMS ( 5 to $28 \mathrm{nM}$ ) concentrations were observed in the MIZ around the Ross and Amundsen Seas and the coastal regions in the Antarctic Peninsula; this could be attributed to biological production of local ice algae, which appears to be supplied with nutrients from glacial or sea ice melt water. These observed DMS inventories were significantly higher (an order of magnitude) than current climatological DMS inventories. The local DMS sources being transported outward from the polynyas, where strong bloom occurs during summer, could result in larger discrepancies between observed DMS and climatological DMS in the MIZ area (in the Amundsen Sea). Overall, this study is the first to highlight the significance of the underestimation of current DMS fluxes in the austral autumn, which consequently results in significant errors in the climate models.
\end{abstract}

Keywords: dimethyl sulfide; Southern Ocean; austral autumn; climate; high-frequency underway observation

\section{Introduction}

Dimethyl sulfide (DMS) is a volatile organic compound produced from the biological activity of plankton in the ocean through the decomposition of algal metabolites, such as dimethylsulfoniopropionate (DMSP). DMS in the atmosphere is photo-oxidized into sulfate $\left(\mathrm{SO}_{4}{ }^{2-}\right)$ aerosols, which play a crucial role in the condensation of nuclei for cloud formation [1]. As a result, the amount of sea-to-air DMS emissions is closely related to variation of the radiative budget [2], and thus directly affects the climate feedback system. Although the overall role of DMS in the climate system is still under debate [3], the influence of DMS could be significant at the regional scale in remote oceans, such as the polar oceans $[4,5]$.

Previous studies suggest that the Southern Ocean is the most important DMS source region [6,7], together with the fact that Antarctic polynyas are some of the most productive regions due to the high terrestrial (via melting glaciers or ice) nutrient supply in the austral summer [8]. Antarctic polynyas could also be a key DMS source region due to the dominance of Phaeocystis antarctica (P. antarctica) in Antarctic water phytoplankton assemblages, which is considered to be a main producer of the DMSP as a DMS precursor [9-11]. As a result, approximately two-fold higher mean concentrations (up to $300 \mathrm{nM}$ ) and fluxes of DMS have recently been reported from the surface waters of western Antarctica as com- 
pared to the open ocean [12,13]. More recently, substantially higher DMS concentrations were also observed in Arctic melt ponds for the first time [14].

Despite the climatological importance of DMS emissions in the polar oceans, these previous studies were generally focused on the summer season, when the sea ice is completely melted, and thus access to the study area is less challenging. However, to elucidate the impacts of the current enhanced DMS emissions in the Southern Ocean on global cooling and further negative impacts on the climate feedback loop in the near future [15,16], longterm (seasonal or annual to decadal) high-resolution investigations of the DMS inventories are necessary. Previous studies on DMS flux estimates from the Southern Ocean have contained large data uncertainties due to the scarcity of measurement data for entire seasons, aside from summer. Thus, the main objective of this study is to evaluate the significance of the DMS inventories in the Southern Ocean in the austral autumn to autumn-winter transition period for the first time (Figure 1). We conducted high-frequency (minimum interval) underway observations of the DMS distribution in the western Antarctic surface waters in April 2018 (the mid-austral autumn), using a recently improved membrane inlet mass spectrometry (MIMS) technique [12,17].

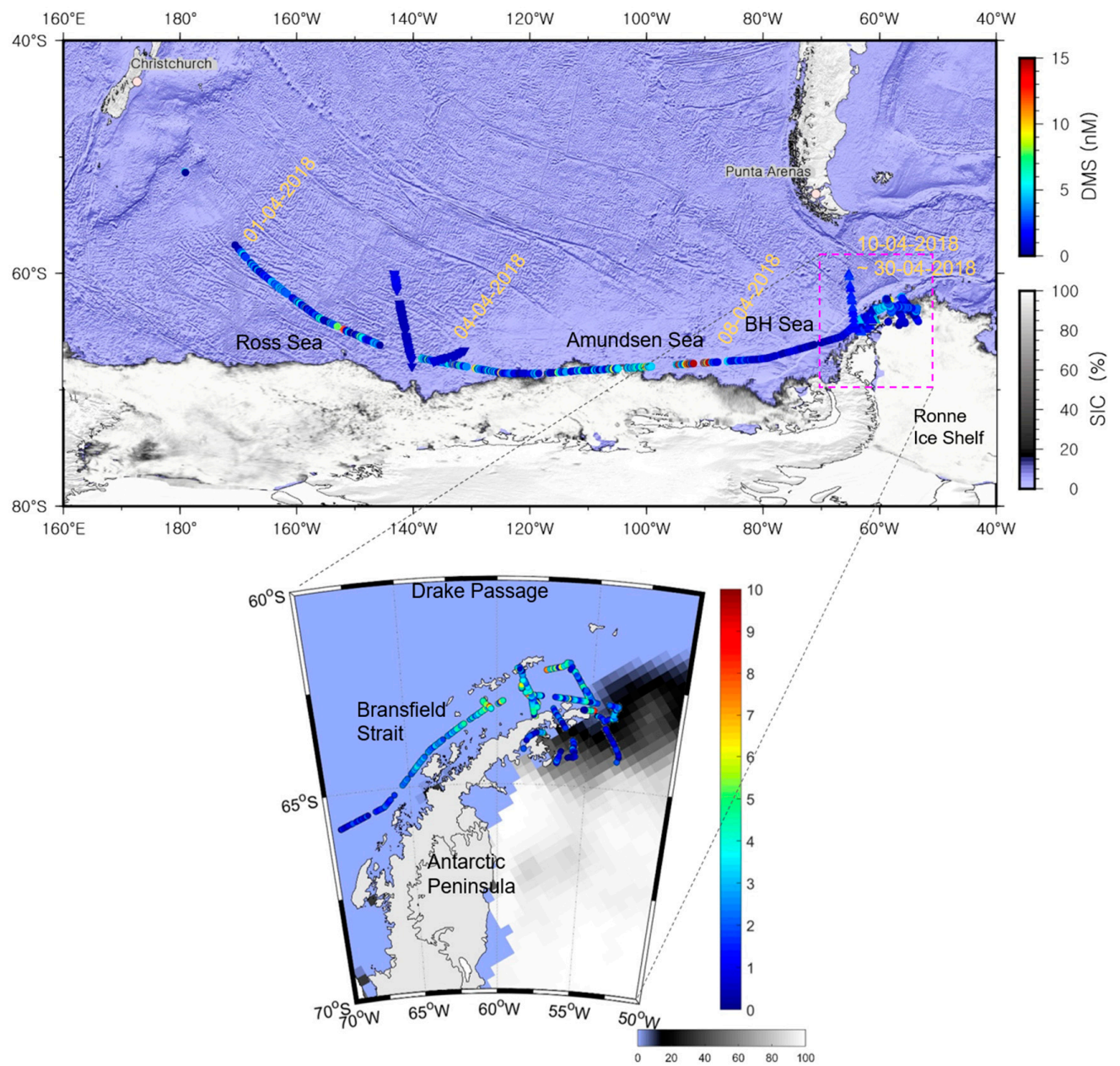

Figure 1. Map of the study area and DMS concentrations (circles) with sea ice concentration (SIC) following the cruise track in the Pacific sector of the Southern Ocean (upper figure), with the map expanded to the Antarctic Peninsula coastal region (lower figure). Triangles and inverted triangles denote the previous DMS data reported by Berresheim [18] and Berresheim et al. [19], respectively. 


\section{Methods}

\subsection{Study Area}

Continuous underway DMS measurements were performed in the surface water of the Southern Ocean (western Antarctic) during mid-autumn (late March to early May) in 2018 onboard the Korean icebreaker R/V Araon. The cruise track covered a range of $50^{\circ} \mathrm{W}$ to $170^{\circ} \mathrm{W}\left(58^{\circ} \mathrm{S}\right.$ to $\left.68^{\circ} \mathrm{S}\right)$ in the Pacific sector of the Southern Ocean, including the marginal (sea) ice zone (MIZ) of the Ross Sea $\left(>140^{\circ} \mathrm{W}\right)$, the Amundsen Sea $\left(140^{\circ} \mathrm{W}-90^{\circ} \mathrm{W}\right)$, the Bellingshausen Sea $\left(90^{\circ} \mathrm{W}-65^{\circ} \mathrm{W}\right.$; Figure 1), and the Antarctic Peninsula region, including the Bransfield Strait (near $62^{\circ} \mathrm{S} 60^{\circ} \mathrm{W}$; red dotted box in Figure 1).

\subsection{Continuous Dissolved Gas Measurements Using the Membrane Inlet Mass Spectrometer}

The analytical methods followed in this study followed the protocols described by Kim et al. [12]. Surface water was collected from the ship's seawater supply at a depth of $7 \mathrm{~m}$. DMS and some major gases (such as $\mathrm{O}_{2}$ and $\mathrm{Ar}$ ) were measured in the same samples using a membrane inlet mass spectrometer (MIMS) (Hiden 301, Warrington, UK) consisting of a secondary electron multiplier (SEM) detector, diaphragm, and turbo pumps (vacuum of $\sim 2 \times 10^{-5}$ Torr), a circular polydimethylsiloxane membrane (20 $\mu \mathrm{m}$ thickness and $3 \mathrm{~cm}$ diameter) enclosed in a cuvette ( $5 \mathrm{~cm}$ diameter), and an electron impact ionization source. DMS (mass-to-charge ratio, $\mathrm{m} / \mathrm{z}=62$ ) and other gases (such as $\mathrm{O}_{2}$ and $\mathrm{Ar}$ ) were measured by the SEM detector and a Faraday cup, respectively, under $500 \mu \mathrm{A}$ of ion source filament current and $1500 \mathrm{~V}$ of SEM acceleration voltage.

Water was collected by a gear pump at a flow rate of $200 \mathrm{~mL} \mathrm{~min}^{-1}$ from the bottom of the glass sample bottles, preventing sample alteration by ambient air. Before the sample introduction, the temperature of the water samples was adjusted to $\sim 2{ }^{\circ} \mathrm{C}$ (similar to ambient seawater) using a coiled heat exchanger (a $6 \mathrm{~m} 1 / 4^{\prime \prime}$ stainless steel tube) and a cooling water bath. After flushing for $2 \mathrm{~min}$, the outlet plastic tubing was moved to the sample bottle from the sink to recirculate the water sample. All samples were analyzed for approximately $7 \mathrm{~min}$ ( $n=10$ runs). There were no noticeable decreases in detection signals in sample measurements, indicating no or insignificant alteration of sample properties during recirculation ( $>45 \mathrm{~s}$ for one sample cycle).

\subsection{Calibration}

The standard solutions were dilutions of a pure DMS solution (>99.0\%, Sigma-Aldrich, St. Louis, MO, USA), and DMS was calibrated using external standards. The concentrations of the standard solutions varied between $1 \mathrm{nM}$ and $50 \mathrm{nM}$. Methanol (HPLC grade) and filtered DMS-free deep water ( $>500 \mathrm{~m}$ depth) were used for media of the primary and working standards, respectively [20]. The stock solutions were sealed gas-tight with minimum headspace and stored in a refrigerator $\left(4^{\circ} \mathrm{C}\right)$ until analyses. Then, the primary standards were diluted to $\sim 520 \mathrm{~mL}$ in glass bottles as working stocks when the calibrations were conducted. The correlation coefficients $\left(R^{2}\right)$ of all the calibration curves were larger than 0.90 . All standards were measure twice, and the mean deviation of duplicates was $<8 \%$.

The $\mathrm{O}_{2} /$ Ar ratio was also calibrated using a deep (sea) water standard (one point calibration) after every DMS calibration. The equilibrated $\mathrm{O}_{2} /$ Ar standard water samples were prepared by gently bubbling fresh air into deep seawater, using a pump, for more than $3 \mathrm{~h}$ in a bath under constant temperature (real-time room temperature). The calibration runs for DMS and $\mathrm{O}_{2} /$ Ar were conducted on a daily basis.

\subsection{Calculation of Oxygen Supersaturation Anomaly $\left(\Delta \mathrm{O}_{2} / \mathrm{Ar}\right)$}

In this study, the biological production is presented as a biological oxygen supersaturation anomaly $\left(\Delta \mathrm{O}_{2} / \mathrm{Ar}\right)$ because dissolved oxygen (DO) could be influenced by not only the biological production but also the various physical processes (e.g., air dissolution, bubble injection, and variability of temperature and air pressure) [6,12]. Instead, the amount of biologically derived $\mathrm{O}_{2}$ can be quantified by the $\mathrm{O}_{2} /$ Ar ratio, based on the geochemical 
characteristics of Ar; Ar shows a similar solubility and diffusivity to $\mathrm{O}_{2}$, but is (biologically) inert. The oxygen supersaturation anomaly is defined as follows:

$$
\Delta \mathrm{O}_{2} / \mathrm{Ar}(\%)=\left\{\left(\mathrm{O}_{2} / \mathrm{Ar}\right)_{\text {measured }} /\left(\mathrm{O}_{2} / \mathrm{Ar}\right)_{\text {saturated }}-1\right\} \times 100
$$

where $\left(\mathrm{O}_{2} / \mathrm{Ar}\right)_{\text {measured }}$ and $\left(\mathrm{O}_{2} / \mathrm{Ar}\right)_{\text {saturated }}$ are the ratios of $\mathrm{O}_{2} / \mathrm{Ar}$ in the samples and air-saturated water, respectively.

\subsection{Other Hydrographic Parameters}

Data for sea ice concentrations (SIC) along the ship cruise track were obtained from Advanced Microwave Scanning Radiometer 2 (AMSR2) daily sea ice maps. The continuous sea surface temperature (SST) and sea surface salinity (SSS) were measured using a thermosalinograph (SBE-45, US) at a precision of $0.002{ }^{\circ} \mathrm{C}$ and $0.0003 \mathrm{mS} / \mathrm{cm}$ (conductivity). Wind speeds were obtained from shipboard data observed at a $10 \mathrm{~m}$ height.

\section{Results and Discussion}

\subsection{Distributions of DMS in the Study Region}

The concentrations of DMS ranged from $<0.5$ to $28 \mathrm{nM}$, with an average of $2.7 \pm 2.5 \mathrm{nM}(n>2680)$ for the entire study area (Figure 1$)$. The higher DMS anomaly values (i.e., more than twice the mean concentration) were regionally observed in the MIZ of the Ross Sea, the Amundsen Sea, and coastal regions around the Antarctic Peninsula. The DMS hotspots where the highly elevated DMS concentrations (20-28 nM) were found were concentrated in the Amundsen Sea region $\left(95^{\circ} \mathrm{W}-90^{\circ} \mathrm{W}\right)$ (Figure 1). Recently, it was documented that several DMS hotspots were observed during the austral summer in the Amundsen Sea, resulting from the higher abundance of plankton biomass polynya, in particular the dominance of $P$. Antarctica [12]. During this study, DMS concentrations in these hotspots were an order of magnitude higher than those in the open ocean (e.g., $0.5-5 \mathrm{nM}$ in the Atlantic and Pacific; data from the PMEL-NOAA data center, https://saga.pmel.noaa.gov/dms/).

In April, although sea ice advances quickly, some biological activity remains due to the local bloom of ice algae (Figure S1) in the MIZs. However, DMS has rarely been studied in this season. In the 1980s-1990s, some DMS data were reported in April near the Amundsen Sea $(0.76 \pm 0.28 \mathrm{nM}, n=81$; data from the PMEL-NOAA data center, https:/ / saga.pmel.noaa.gov/dms/) and Bransfield Strait (1.9 $\pm 1.2 \mathrm{nM}, n=113)[19,20]$, respectively from two campaigns (Figure 1). However, in these previous studies, no elevated DMS concentrations (e.g., > $>\mathrm{nM}$ ) or DMS hotspots were observed. The regional significant enhancement of DMS concentrations in this study could be attributed to (i) high-resolution detection of DMS hotspots or (ii) up-to-date enhanced production with increasing terrestrial nutrients via melting glaciers and ice in recent years [12,13].

\subsection{Factors Controlling the Production of DMS in Austral Autumn}

To identify the factors responsible for the increased production of DMS in autumn in the Southern Ocean, the time series of hydrographic data (SST, SSS, SIC, and wind speed) and $\Delta \mathrm{O}_{2} /$ Ar are shown together with DMS in Figure 2. Because net community production is deduced when the biological oxygen $\left(\Delta \mathrm{O}_{2} / \mathrm{Ar}\right)$ is multiplied by gas transfer velocity, we used $\Delta \mathrm{O}_{2} / \mathrm{Ar}$ as a representative parameter of biological production in the surface layer. Although these variables might not be sufficient to fully understand the complex DMS creation and removal processes, they are typical variables describing the physical and biological environment of the polar ocean [12,17]. The DMS concentrations were found to be higher mainly in areas with less SIC. However, overall, among those variables, there was no strong correlation between each variable (Figure 2). However, in early April, the SSS and SST were noticeably lower (but $\Delta \mathrm{O}_{2} / \mathrm{Ar}$ was higher) in the Amundsen Sea relative to those in the Bellingshausen Sea (Figure 2). Thus, the much higher DMS inventory in the Ross and Amundsen Seas than in the Bellingshausen Sea could be due to the significant portions of meltwater (with low temperature and salinity, 
highly fertilized) that were introduced offshore of the Amundsen Sea via outward currents (major direction is towards the Ross Sea). In addition, the DMS increased (5-10 nM) in the Bransfield strait region (Figure 1) around the Antarctic Peninsula. In this coastal region, a higher $\Delta \mathrm{O}_{2} / \mathrm{Ar}$ associated with decreases in both SST and SSS was also observed (around 26 April), which was similar to the pattern in the MIZ of the Amundsen Sea (Figure 2). Overall, there was no strong correlation between DMS enrichment and any specific variable. Therefore, the elevated DMS concentrations $(>5 \mathrm{nM})$ in the offshore region were speculated to be related to the enhancement of local biological production, fertilized by outward transportation of ice melt water from polynyas in the austral summer. Here, we also noted that the DMS distributions in mid-autumn were thought to be determined by the combined processes of various biogeochemical factors, such as productivity, SIC, hydrography, and phytoplankton assemblage [12].

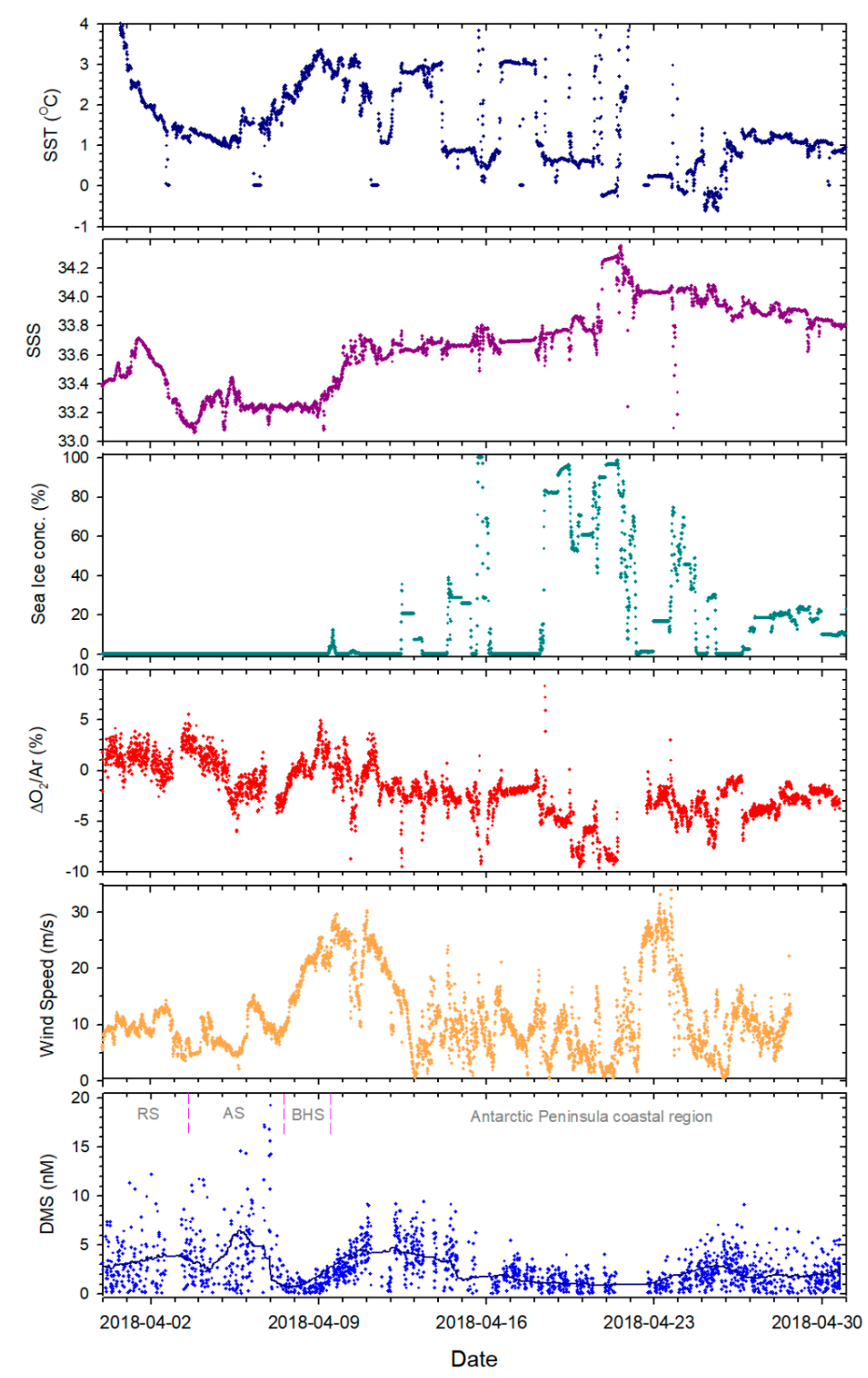

Figure 2. Time series of underway measurements of SST, SSS, sea ice concentration, $\mathrm{O}_{2} / \mathrm{Ar}(\%)$, wind speed, and DMS. Note that the scale of the y-axis in DMS concentrations is 20, but in fact values exceeding $20 \mathrm{nM}$ were observed a total of four times $(20.5,23.6,26.8$, and $28.0 \mathrm{nM})$. For the Amundsen Sea region, see Supplementary Materials. Line plots in the DMS indicate $(24 \mathrm{~h})$ the moving average of DMS concentrations. 


\subsection{Comparisons of DMS Observation Data in This Study to Climatological DMS}

We analyzed three recent climatological DMS inventories to evaluate the DMS discrepancies between current estimates and our direct measurements. Inventories originated from previous works by Lana et al. [21] (hereafter referred to as L11), Gali et al. [22] (hereafter referred to as G18), and Wang et al. [23] (hereafter referred to as W20). All these inventories were re-gridded into the $1^{\circ} \times 1^{\circ}$ spatial resolution for comparison (Figure 3). L11 has been frequently used in climate model simulations [24,25], and the DMS concentrations are deduced by the observed DMS concentration data sets applying objective analysis approach, which fills the spatial and temporal measurement gaps using multiple interpolation and extrapolation techniques. The calculated DMS concentrations using G18 from the algorithms were developed by using satellite datasets and rigorous consideration of non-linear relationships between DMS and plankton light exposure. Recently, DMS concentrations for W20 were estimated from artificial neural network analysis, giving the most extensive observational dataset (82,996 measurements) (Figure 3). Note that the comparison between the direct onboard measurement and the time-averaged climatological inventories bears uncertainties from the spatial and temporal scale mismatch. Also, in coastal regions, G18 and W20 do not have sufficient satellite inputs including sea ice concentration. However, because this the is first observation in the autumn in the West Antarctic region, the comparison clearly provides a basis for updating the current understanding on the DMS emissions in the polar region.

The estimated DMS from all three approaches tended to estimate DMS concentrations constrained within 0.5 and 1.5 for almost all the Southern Ocean (Figure 3). The exception was the L11 estimates for Western Antarctica and the Antarctic Peninsula (Figure 3c), where our study area was located. When the measured DMS concentrations (for 6-h average) were compared to the estimated climatological DMS inventories, almost half of the observed DMS inventories agreed well with climatological DMS inventories. However, the other half were 2 to 30 times higher than estimated values, in particular in the western Antarctic seas (Ross and Amundsen Seas until 10 April) and some coastal regions around Bransfield Strait (end of April) (Figure 4). The discrepancies (in the range of 1 to $17 \mathrm{nM}$ ) between observed and climatological estimates were mainly attributed to the mismatch of spatial (in situ observation point and $1^{\circ} \times 1^{\circ}$ gridded mean) and temporal (6-h mean and monthly mean) resolution. The much larger discrepancy in the Amundsen Sea (early April) relative to the Antarctic Peninsula (end of April) could be associated with the local DMS sources transported outward from the polynyas (Figure 4), where the high production occurred during the austral summer $[6,12,13]$. Therefore, the MIZ (early April) of the Amundsen Sea appears to show a particularly large error between observed and climatological data (Figure 4). Overall, we found significant underestimation of current DMS inventories in comparison with direct observations. The results suggest that high-resolution observations are essential in order to correct the regional climatological datasets, and also imply that the updated inventories will play an important role in improving the accuracy of future climate predictions. 

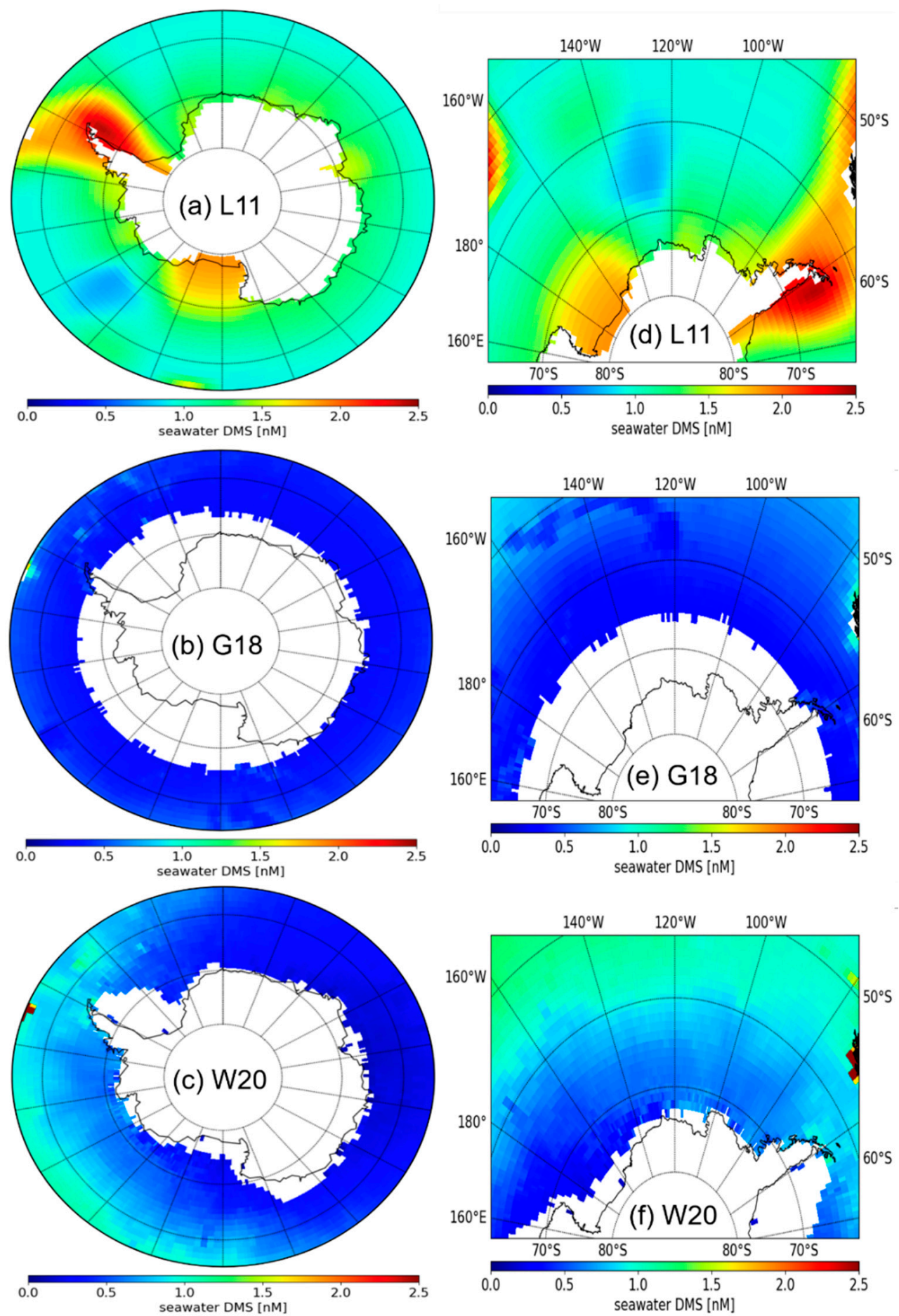

Figure 3. Maps of DMS levels estimated from three different inventories: $(\mathbf{a}-\mathbf{c})$ map of the entire Southern Ocean; (d-f) map of the Antarctic Peninsula coastal region. L11, G18, and W20 represent the data from Lana et al. [21], Gali et al. [22], and Wang et al. [23], respectively. 

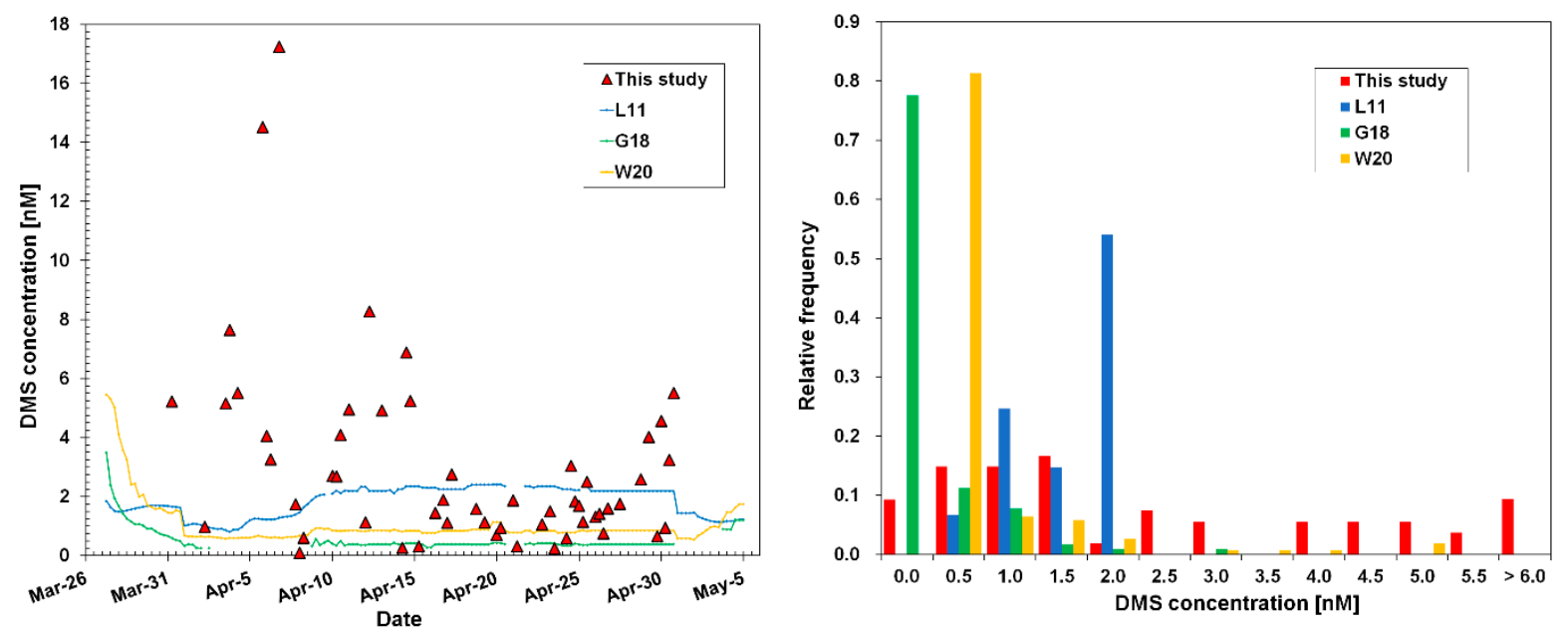

Figure 4. (Left pane) Comparisons of observed DMS concentrations (for $12 \mathrm{~h}$ average from this study, red triangles) with corresponding climatological seawater DMS concentrations estimated from three different emission inventories. Blue, green, and yellow dots denote the DMS inventories from Lana et al. [21], Gali et al. [22], and Wang et al. [23], respectively. (Right pane) Frequency distribution of DMS concentrations for the corresponding datasets in the left pane.

\subsection{Significance of DMS Flux in the Southern Ocean in Autumn}

In this study, we estimated the sea-to-air DMS fluxes from measurements. The DMS fluxes $\left(\mathrm{F}_{\mathrm{DMS}}\right.$ ) via sea-air exchange (assuming that atmospheric concentrations of DMS are negligible in austral autumn) in our study area were calculated as follows:

$$
\mathrm{F}_{\mathrm{DMS}}=(1-i) \times k \times D M S_{S W}
$$

where $i$ is the fraction of ice-covered surface area (represented by SIC), DMS $S_{S W}$ is the DMS concentration $\left(\mathrm{mol} \mathrm{m}^{-3}\right)$ in the surface water, and $k$ is the gas transfer (piston) velocity of DMS $\left(\mathrm{cm} \mathrm{h}^{-1}\right)$, based on (i) an instantaneous observed wind speed $\left(\mathrm{m} \mathrm{s}^{-1}\right)$, (ii) the coefficient relationship documented by Nightingale et al. [26] (hereafter referred to as N00) and Wanninkhof et al. [27] (hereafter referred to as W14), and (iii) normalized to Schmidt number (Sc) for DMS according to Saltzman et al. [28]. The average DMS fluxes from the entire study area in this observation were calculated to be $0.013 \pm 0.020 \mathrm{mmol} \mathrm{m}^{-2} \mathrm{~d}^{-1}$ and $0.014 \pm$ $0.023 \mathrm{mmol} \mathrm{m} \mathrm{m}^{-2} \mathrm{~d}^{-1}$, based on N00 and W14, respectively. These average DMS fluxes in April were comparable within an order of magnitude to previously reported DMS fluxes in Amundsen Sea polynya in the summer season $\left(0.053-0.085 \mathrm{mmol} \mathrm{m}^{-2} \mathrm{~d}^{-1}\right)[6,12]$. In addition, the DMS fluxes in this study were an order of magnitude higher than the climatological estimation of the annual DMS flux for the entire Southern Ocean $\left(0.0067 \mathrm{mmol} \mathrm{m}^{-2} \mathrm{~d}^{-1}\right)$ [21] and global oceans $\left(0.0022-0.0038 \mathrm{mmol} \mathrm{m}^{-2} \mathrm{~d}^{-1}\right)$ [22,23]; both of these results were also quantified using N00 and converted into daily units for convenience of comparison.

Most areas of the Southern Ocean (south of $40^{\circ} \mathrm{S}$ ) are far away from human-inhabited continents. Accordingly, the surface of the ocean at this latitude has been regarded as a potentially important major source of atmospheric biogenic sulfur (compounds) because of the high productivity rates and the intensive winds with the absence of major interference from continental air masses [19]. In this study, the strong winds (with an average wind speed of 10 to $30 \mathrm{~m} \mathrm{~s}^{-1}$ ) also lasted nearly half the observation period (especially 20-30 $\mathrm{m} \mathrm{s}^{-1}$ in the Bransfield Strait), even though there were no extremely high DMS hotspots (such as $>100 \mathrm{nM}$, often observed in summer) in April. More recently, Zhang et al. [7] documented that sometimes DMS fluxes in summer could be lower than those in other seasons, since the DMS concentration in the atmosphere is already high in summer. Thus, our results suggest that the DMS fluxes during the autumn were evidently underestimated compared to the previous estimates. Further studies are also necessary to clarify the 
atmospheric processes of the sulfur cycle, as well as to acquire more realistic climate model simulation results.

\section{Conclusions}

We investigated the surface dimethyl sulfide (DMS) distribution in the Southern Ocean in April, a period when the DMS distributions are rarely studied. Substantially higher DMS (5 to $30 \mathrm{nM}$ ) concentrations were observed in the marginal ice zone (MIZ) in the western Antarctic and coastal waters around the Antarctic Peninsula, using a high frequency observation. The relatively higher DMS concentrations were attributed to biological production of local ice algae, which appears to be supplied with nutrients from glacial and ice melt water. We also found significant underestimation of the current climatological DMS inventories in comparison with the direct observations in this study, especially on the surface of the ocean around the MIZ. These results suggest that climatology-based DMS fluxes in the austral autumn, which are currently used in climate models, could be largely underestimated based on both the (i) strong wind and (ii) lower atmospheric DMS inventory in this season. Our results imply that high-resolution observations of DMS fluxes in seasons other than summer are imperative in order to calibrate the current climatological DMS inventories, which are significantly underestimated. Furthermore, more extensive studies on the sources of atmospheric sulfur compounds are necessary in order to improve the accuracy of future climate forecasts.

Supplementary Materials: The following are available online at https:/ / www.mdpi.com/2073-443 3/12/1/122/s1, Figure S1: Massive sea ice algae colonies encountered in the Antarctic Peninsula sea ice zone and the raw data file.

Author Contributions: I.K. and K.P. conducted post-processing of data sets and flux calculations. M.Z. significantly contributed to discussion. K.P. and K.K. designed the research and conducted the field campaign. All authors were actively involved in writing and revising the manuscript. All authors have read and agreed to the published version of the manuscript.

Funding: This research was funded by Korea Polar Research Institute (PE21110 and PE21120) and also supported by the international cooperation program managed by the National Research Foundation of South Korea (NRF-2019K2A9A2A06025329). I.K. is supported by grants from the “KIOST Indian Ocean Study" (PE99912) and National Research Foundation of Korea (PN68460). M.Z. is supported by grants from the National Natural Science Foundation of China (NSFC) (4207060283 and 41911540471).

Acknowledgments: We thank the captain and all the crewmembers of the icebreaker IBR/V Araon, who helped with onboard sampling during the ANA08D cruise. We also thank Jung-Ok Choi, who helped with the processing of the dataset. All datasets used in this paper are available upon request from the corresponding author (keyhongpark@kopri.re.kr).

Conflicts of Interest: The authors declare no conflict of interest.

\section{References}

1. Kettle, A.J.; Andreae, M.O.; Amouroux, D.; Andreae, T.W.; Bates, T.S.; Berresheim, H.; Bingemer, H.; Boniforti, R.; Curran, M.A.J.; DiTullio, G.R.; et al. A global database of sea surface dimethylsulfide (DMS) measurements and a procedure to predict sea surface DMS as a function of latitude, longitude, and month. Glob. Biogeochem. Cycles 1999, 13, 399-444. [CrossRef]

2. Charlson, R.J.; Lovelock, J.E.; Andreae, M.O.; Warren, S.G. Oceanic phytoplankton, atmospheric sulphur, cloud albedo and climate. Nature 1987, 326, 655. [CrossRef]

3. Quinn, P.K.; Bates, T.S. The case against climate regulation via oceanic phytoplankton sulphur emissions. Nature 2011, $480,51$. [CrossRef]

4. Lana, A.; Simó, R.; Vallina, S.M.; Dachs, J. Re-examination of global emerging patterns of ocean DMS concentration. Biogeochemistry 2012, 110, 173-182. [CrossRef]

5. Woodhouse, M.T.; Mann, G.W.; Carslaw, K.S.; Boucher, O. Sensitivity of cloud condensation nuclei to regional changes in dimethyl-sulphide emissions. Atmos. Chem. Phys. 2013, 13, 2723-2733. [CrossRef]

6. Tortell, P.D.; Long, M.C.; Payne, C.D.; Alderkamp, A.C.; Dutrieux, P.; Arrigo, K.R. Spatial distribution of $\mathrm{pCO}_{2}, \Delta \mathrm{O}_{2} / \mathrm{Ar}$ and dimethylsulfide (DMS) in polynya waters and the sea ice zone of the Amundsen Sea, Antarctica. Deep Sea Res. Part II 2012, 71, 77-93. [CrossRef] 
7. Zhang, M.; Park, K.T.; Yan, J.; Park, K.; Wu, Y.; Jang, E.; Gao, W.; Tan, G.; Wang, J.; Chen, L. Atmospheric dimethyl sulfide and its significant influence on the sea-to-air flux calculation over the Southern Ocean. Progr. Oceanogr. 2020, 186, 102392. [CrossRef]

8. Boyd, P.W. The role of iron in the biogeochemistry of the Southern Ocean and equatorial Pacific: A comparison of in situ iron enrichments. Deep Sea Res. Part II 2002, 49, 1803-1821. [CrossRef]

9. Stefels, J.; Van Boekel, W.H.M. Production of DMS from dissolved DMSP in axenic cultures of the marine phytoplankton species Phaeocystis sp. Mar. Ecol. Prog. Ser. 1993, 97, 11-18. [CrossRef]

10. DiTullio, G.R.; Smith, W.O. Relationship between dimethyl sulfide and phytoplankton pigment concentrations in the Ross Sea, Antarctica. Deep Sea Res. Part I 1993, 42, 873-892. [CrossRef]

11. DiTullio, G.R. Dimethylsulfide concentrations in the southern Ross Sea during austral summer 1995-1996. Antarct. J. US 1993, 31, 127-128.

12. Kim, I.; Hahm, D.; Park, K.; Lee, Y.; Choi, J.O.; Zhang, M.; Chen, L.; Lee, S. Characteristics of the horizontal and vertical distributions of dimethyl sulfide throughout the Amundsen Sea Polynya. Sci. Total Environ. 2017, 584, 154-163. [CrossRef] [PubMed]

13. Zhang, M.; Marandino, C.A.; Chen, L.; Sun, H.; Gao, Z.; Park, K.; Kim, I.; Yang, B.; Zhu, T.; Yan, J.; et al. Characteristics of the surface water $\mathrm{DMS}$ and $\mathrm{pCO}_{2}$ distributions and their relationships in the Southern Ocean, southeast Indian Ocean, and northwest Pacific Ocean. Glob. Biogeochem. Cycles 2017, 31, 1318-1331. [CrossRef]

14. Park, K.; Kim, I.; Choi, J.O.; Lee, Y.; Jung, J.; Ha, S.Y.; Kim, J.H.; Zhang, M. Unexpectedly high dimethyl sulfide concentration in high-latitude Arctic sea ice melt ponds. Environ. Sci. Process. Impacts 2017, 21, 1642-1649. [CrossRef]

15. Bopp, L.; Boucher, O.; Aumont, O.; Belviso, S.; Dufresne, J.L.; Pham, M.; Monfray, P. Will marine dimethyl sulfide emissions amplify or alleviate global warming? Amodel study. Can. J. Fish. Aquat. Sci. 2004, 61, 826-835. [CrossRef]

16. Cameron-Smith, P.; Elliott, S.; Maltrud, M.; Erickson, D.; Wingenter, O. Changes in dimethyl sulfide oceanic distribution due to climate change. Geophys. Res. Lett. 2011, 38, 38. [CrossRef]

17. Tortell, P.D. Dissolved gas measurements in oceanic waters made by membrane inlet mass spectrometry. Limnol. Oceanogr. Meth. 2005, 3, 24-37. [CrossRef]

18. Berresheim, H. Biogenic sulfur emissions from the Subantarctic and Antarctic Oceans. J. Geophys. Res. Atmos. 1987, 92, 13245-13262. [CrossRef]

19. Berresheim, H.; Andreae, M.O.; Ayers, G.P.; Gillett, R.W. Distribution of biogenic sulfur compounds in the remote southern hemisphere. In Biogenic Sulfur in the Environment; Saltzman, E.S., Cooper, W.J., Eds.; American Chemical Society (ACS): Washington, DC, USA, 1989; pp. 352-366.

20. Stefels, J. Chapter 11. Determination of DMS, DMSP, and DMSO in Seawater. In Practical Guidelines for the Analysis of Seawater; Wurl, O., Ed.; CRC Press: Boca Raton, FL, USA, 2009.

21. Lana, A.; Bell, T.G.; Simó, R.; Vallina, S.M.; Ballabrera-Poy, J.; Kettle, A.J.; Dachs, J.; Bopp, L.; Saltzman, E.S.; Stefels, J.; et al. An updated climatology of surface dimethlysulfide concentrations and emission fluxes in the global ocean. Glob. Biogeochem. Cycles 2011, 25, GB1004. [CrossRef]

22. Gali, M.; Levasseur, M.; Devred, E.; Simo, R.; Babin, M. Sea-surface dimethylsulfide (DMS) concentration from satellite data at global and regional scales. Biogeosciences 2018, 15, 3497-3519. [CrossRef]

23. Wang, W.L.; Song, G.; Primeau, F.; Saltzman, E.S.; Bell, T.G.; Moore, J.K. Global ocean dimethyl sulfide climatology estimated from observations and an artificial neural network. Biogeosciences 2020, 17, 5335-5354. [CrossRef]

24. Hodshire, A.L.; Campuzano-Jost, P.; Kodros, J.K.; Croft, B.; Nault, B.A.; Schroder, J.C.; Jimenez, J.L.; Pierce, J.R. The potential role of methanesulfonic acid (MSA) in aerosol formation and growth and the associated radiative forcings. Atmos. Chem. Phys. 2019, 19,3137-3160. [CrossRef]

25. Mahmood, R.; von Salzen, K.; Norman, A.L.; Gali, M.; Levasseur, M. Sensitivity of Arctic sulfate aerosol and clouds to changes in future surface seawater dimethylsulfide concentrations. Atmos. Chem. Phys. 2019, 19, 6419-6435. [CrossRef]

26. Nightingale, P.D.; Malin, G.; Watson, A.J.; Liss, P.S. In situ evaluation of air-sea gas exchange parameterizations using novel conservative and volatile tracers. Glob. Biogeochem. Cycles 2000, 14, 373-387. [CrossRef]

27. Wanninkhof, R. Relationship between wind speed and gas exchange over the ocean revisited. Limnol. Oceanogr. Meth. 2014, 12, 351-362. [CrossRef]

28. Saltzman, E.S.; King, D.B.; Holmen, K.; Leck, C. Experimental determination of the diffusion coefficient of dimethyl sulfide in water. J. Geophys. Res. Oceans 1993, 98, 16481-16486. [CrossRef] 